DOI: 10.20472/IAC.2020.053.001

MAY ALASHWAL

Department of Learning Sciences and Educational Research, University of Central Florida, USA, Saudi Arabia

\title{
A STUDY ON WEB 2.0 TECHNOLOGIES INTEGRATION CHALLENGES AND CHANGES IN SAUDI ARABIAN UNIVERSITIES
}

\begin{abstract}
:
This study was applied within two universities in the western part of Saudi Arabia. The universities intend to implement and apply Web 2.0 tools to help lecturers and faculty enhance teaching and training at both undergraduate and graduate levels. The research was carried out to determine the associated challenges and changes in applying Web 2.0 at two Saudi universities in order to assess the decision of whether or not to adopt such technology. The results demonstrated that lecturers and faculties in the two Saudi universities were willing to accept the new challenges and changes to embrace Web 2.0. Additional results showed their enthusiasm to improve the learning process and to enhance interactions with students.
\end{abstract}

\section{Keywords:}

Web 2.0; Technologies; Lifelong learning; Faculty perceptions 


\section{Introduction}

Today, students communicate in many ways and frequently complete assignments using cell phones, submitting them via social networking websites. Web technologies such as Blackboard and Webcourses and applications such as WhatsApp and Messenger have been increasingly used by students and have significantly improved course delivery at many universities (Barnett, Keating, Harwook, \& Saam, 2004). Accordingly, the two selected Saudi universities intend to modernize their knowledge delivery and traditional classrooms with tier students. The importance and emergence of the instructional tools and technologies are positively changing the academic environment by improving teaching and knowledge delivery in the digital age (Collins \& Halverson, 2010). The increased use of Web 2.0 tools at many universities around the globe has improved higher education deliverables because students are already using them in non-classroom activities (Seo, 2013). The Saudi Arabian government, represented by the Ministry of Education, has pushed for the implementation of Web 2.0 in the educational system by providing the required resources for funding, manpower, and time (Khawaji, 2016). However, providing these tools and technologies does not mean that they will be used among faculties and their students (Mason, 2016).

The aim of this quantitative study is to explore the challenges and changes associated with implementing Web 2.0 tools by the faculties in Saudi Arabian university classrooms. It is based on designing variables that analyze these challenges and changes in regard to Saudi Arabian faculties. It also shows the current status and experience of the Web 2.0 tools currently being used by the faculties.

\section{Literature Review}

Methods of communicating, teaching, and learning have changed substantially due to the enormous amount of technological innovations in recent times. It has becoming particularly challenging for educational and training institutes to keep up and remain competitive in such a progressive age. Therefore, many institutes are taking advantage of modern tools and technologies (Collins \& Halverson, 2010, p.19). Specifically, the formation of the e-learning teaching style is a result of combining information technology with education. The common tool of e-learning to share knowledge is the World Wide Web. Moreover, students today are more actively participating in using unconventional learning methods such as podcasts, social networking sites, and blogs (Mason, 2016). Studies show that students mostly share or search for information via Web 2.0 tools and technologies (Aifan, 2015), which are made up of webbased technologies and applications that contain user-generated information and content (Kassens-Noor, 2012). Research illustrates that web-based technologies and applications positively affect students' learning (Konstantinidis, Theodostadou, \& Pappos, 2013).

The Saudi Arabian Ministry of Education in 2017 reported that there were approximately 1.6 million students in higher education and 84,000 faculty members, $60 \%$ of whom are Saudis. There were 38 and 30 public and private universities, respectively (Higher Education Statistics, 2017). The university educational system in Saudi Arabia is progressively changing from a traditional to a more blended system (Alturki, 2014). The progressive change is supported by 
the Saudi Ministry of Education to keep on track with all the changes in the leading world educational systems to maintain a high quality of delivering knowledge. For example, the Ministry founded a National Center for e-Learning and Distance Education that aims to adopt the new emerging technologies in Saudi universities (Al-Khalifa, 2010). The national center supports universities' research with advanced technologies and encourages online and webbased education (Khawaji, 2016). The Ministry also encouraged all public universities to establish a Deanship for E-learning and Distance Education that aims to organize seminars and training sessions for faculty members to utilize the advanced technologies in the teaching process with students (Alkhalaf, Nguyen, Nguyen, \& Drew, 2013). However, recent studies show that all of these efforts to integrate Web 2.0 tools into the universities' educational systems did not reach a level deemed to be satisfactory by the Ministry (Al-Hojailan, 2013). Several issues have resulted in the current situation, such as poor infrastructure and a lack of awareness (Al-Asmari \& Khan, 2014). This study determined the challenges faced and changes required by the faculties in adopting Web 2.0 tools.

\section{Methodology}

\subsection{Research Question}

This research is designed to answer the following questions:

Research Question 1: What are the perceptions of Saudi Arabian faculty about using Web 2.0 Tools and technologies in the classroom?

Research Question 2: What are the Saudi Arabian faculty challenges when using Web 2.0 tools?

\subsection{Research Design}

The work adopted a non-experimental, survey quantitative research design to determine Saudi Arabian faculty perceptions on Web 2.0 tools and the challenges they face to integrate these tools into their classroom. The quantitative research relied on data gathered by a crosssectional survey distributed to faculties in two universities in western Saudi Arabia. The survey included items regarding faculty comfort level with Web 2.0 tools, benefits of using Web 2.0 in the classroom, usage and intention to use Web 2.0 tools, and demographics.

\subsection{Research Sampling}

Both universities selected for analysis segregate male from female campuses. The authors obtained permission from the Deanship of Graduate Studies at both universities to carry out this study. An electronic survey was sent to all participants through the Deanship of Graduate Studies. The participants voluntarily responded to the surveys via their emails. There were 73 participants in total. Table 1 outlines responders' profiles. 
Table 1: Responder profiles

\begin{tabular}{lll}
\hline Variable & Value & Frequency \\
\hline Gender & Male & 24 \\
& Female & 49 \\
Age & Under 30 years & 4 \\
& $31-39$ years & 28 \\
& $40-49$ years & 34 \\
Role at & $50-59$ years & 7 \\
university & Lecturer/Visiting professor & 21 \\
& Assistant Professor & 39 \\
& Associated Professor & 3 \\
& Professor & 4 \\
Years of & Graduate & 6 \\
teaching & $1-5$ years & 33 \\
& $6-10$ years & 22 \\
& $11-15$ years & 7 \\
& $16-20$ years & 5 \\
& 21 years or more & 6 \\
\hline
\end{tabular}

\subsection{Data Collection}

After the Deanship of Graduate Studies granted permission for research at both universities, invitation emails were sent to prospective participants with a link to the online survey, which used Dillman and colleagues' (2014) online survey method. The email contained a descriptive paragraph of the study's purpose and how the data would be used.

\subsection{Data Analysis}

The study used descriptive and inferential statistical methods for the research questions analysis using the SPSS software package. The participant background information was determined by the first part of the questionnaire. In the survey, the Web 2.0 technologies and application examples were as set out in Table 2.

Table 2: Web 2.0 technologies and applications listed in the survey

\begin{tabular}{ll}
\hline Technologies & Applications \\
\hline Social Networking & $\begin{array}{l}\text { Facebook Twitter, and } \\
\text { Linkedln } \\
\text { Sites: }\end{array}$ \\
Instant Messaging: & WhatsApp and iMessage \\
Media Sharing: & YouTube, Instagram, and \\
& Flickr \\
\hline
\end{tabular}




\subsection{Results and Discussion}

The survey was sent via email and was available for 40 days. The survey response rate was low in the first invitation (13 participants); however, the follow-up emails increased the number to 73 participants. The data were analyzed with SPSS software package.

The participants sorted the Web 2.0 tools and technologies in ranks based on levels of how to use them in performing the teaching and learning tasks. It was also sorted by how efficient they can be utilized and how they may potentially benefit their students. Answers from the first survey part are shown in Table 3. Answers related to the improvement of faculties' interactions with their students were in the following scenario: more than $50 \%$ of the faculties claimed that social networking, instant messaging, and media sharing would improve such interactions. These percentages were the highest among all other changes' effects. However, less than $50 \%$ of the faculties claimed that these tools and technologies would not improve students' learning. In terms of improving students' satisfaction with the course, instant messaging received the highest percentage $(62 \%)$, whereas the participants demonstrated that social networking and media sharing had lower effects (33\% and $16 \%$, respectively). Regarding student-to-student interaction improvements, most of the faculties commented that social networking and instant messaging are likely to improve the interactions among students to a significant degree, whereas a lower percentage considered that media sharing would have any effects on it. Approximately $50 \%$ of the faculties considered social networking and instant messaging to be easily integrated into their courses, whereas media sharing obtained the lowest percentage $(25 \%)$. In the same manner, most of the faculties claimed that social networking $(76 \%)$ and instant messaging $(66 \%)$ could be possibly integrated into their courses, whereas they noted that media sharing would not particularly affect the interactions $(30 \%)$. However, approximately half of the faculties view social networking (42\%), instant messaging $(50 \%)$, and media sharing $(55 \%)$ as potentially improving their students' grades. However, less than one third believed that all three Web 2.0 tools would not improve their students' writing skills.

Table 3: Saudi Arabian faculties response to current changes' effects of using Web 2.0 Tools

\begin{tabular}{lccc}
\hline & $\begin{array}{c}\text { Social } \\
\text { Networking }\end{array}$ & $\begin{array}{c}\text { Instant } \\
\text { Messagin } \\
\text { g }\end{array}$ & $\begin{array}{c}\text { Media } \\
\text { Sharing }\end{array}$ \\
\hline $\begin{array}{l}\text { Improve student- } \\
\text { faculty interaction }\end{array}$ & $47.3 \%$ & $53.3 \%$ & $55.8 \%$ \\
$\begin{array}{l}\text { Improve students' } \\
\text { learning }\end{array}$ & $33.4 \%$ & $49.6 \%$ & $29.4 \%$ \\
$\begin{array}{l}\text { Improve students' } \\
\text { satisfaction with the } \\
\text { course }\end{array}$ & $33.2 \%$ & $62.3 \%$ & $16.3 \%$ \\
$\begin{array}{l}\text { Improve student- } \\
\text { student interaction }\end{array}$ & $66.7 \%$ & $76.8 \%$ & $34.6 \%$ \\
\hline
\end{tabular}




\begin{tabular}{|c|c|c|c|}
\hline $\begin{array}{l}\text { It could be easily } \\
\text { integrated into my } \\
\text { course }\end{array}$ & $47.3 \%$ & $53.6 \%$ & $25.6 \%$ \\
\hline $\begin{array}{l}\text { It could be } \\
\text { effectively } \\
\text { integrated into my } \\
\text { course }\end{array}$ & $76.4 \%$ & $56.2 \%$ & $30.4 \%$ \\
\hline $\begin{array}{l}\text { Improve students' } \\
\text { grades }\end{array}$ & $42.4 \%$ & $50.4 \%$ & $55.8 \%$ \\
\hline $\begin{array}{l}\text { Improve students' } \\
\text { writing ability }\end{array}$ & $13.1 \%$ & $27.6 \%$ & $8.5 \%$ \\
\hline
\end{tabular}

The measures of central tendency were calculated and summarized in Table 4 (Harpe, 2015). The results reveal that most faculties never used social networking in their courses, yet they were willing to in the future. However, the majority claimed that they frequently used instant messaging and always used media sharing to explain their topics in their classes.

Table 4: Statistical data for faculty's Web 2.0 tools preference.

\begin{tabular}{lccc}
\hline & $\begin{array}{c}\text { Social } \\
\text { Networki } \\
\text { ng Usage }\end{array}$ & $\begin{array}{c}\text { Instant } \\
\text { Messaging } \\
\text { Usage }\end{array}$ & $\begin{array}{c}\text { Media Sharing } \\
\text { Usage }\end{array}$ \\
\hline $\mathbf{N}$ Valid & 73 & 73 & 73 \\
\cline { 2 - 4 } $\begin{array}{l}\text { Missin } \\
\text { g }\end{array}$ & 2 & 2 & 2 \\
\hline Mode & 2 & 4 & 5 \\
\hline Range & 4 & 4 & 3 \\
\hline
\end{tabular}

Note: corresponding values for Mode: $0=$ NA, $1=$ Do not use and never used it, $2=$ Do not use but willing to, $3=$ often used, 4 = frequently used, and 5 = always used.

The faculty's comfort level in using Web 2.0 tools in their courses are described in Table 5 and Figure 1. The results show that approximately $90 \%$ of faculties were either competent or proficient in using social networking. Similarly, around $86 \%$ were proficient in using instant messaging. Moreover, approximately $92 \%$ are either competent or proficient in applying media sharing in their courses. Hence, there was some discrepancy between faculty's Web 2.0 tool preferences and their competency regardless of how experienced they were in using these tools. 
Table 5: Faculty's comfort level with Web 2.0 Tools

\begin{tabular}{lcccc}
\hline & Never Use & Novice & Competent & Proficient \\
\hline $\begin{array}{l}\text { Social } \\
\text { Networking }\end{array}$ & $5.6 \%$ & $3.2 \%$ & $45.7 \%$ & $45.5 \%$ \\
\hline $\begin{array}{l}\text { Instant } \\
\text { Messaging }\end{array}$ & 0 & $1.6 \%$ & $11.7 \%$ & $86.7 \%$ \\
\hline Media Sharing & $1.1 \%$ & $6.2 \%$ & $41.7 \%$ & $51.0 \%$ \\
\hline
\end{tabular}

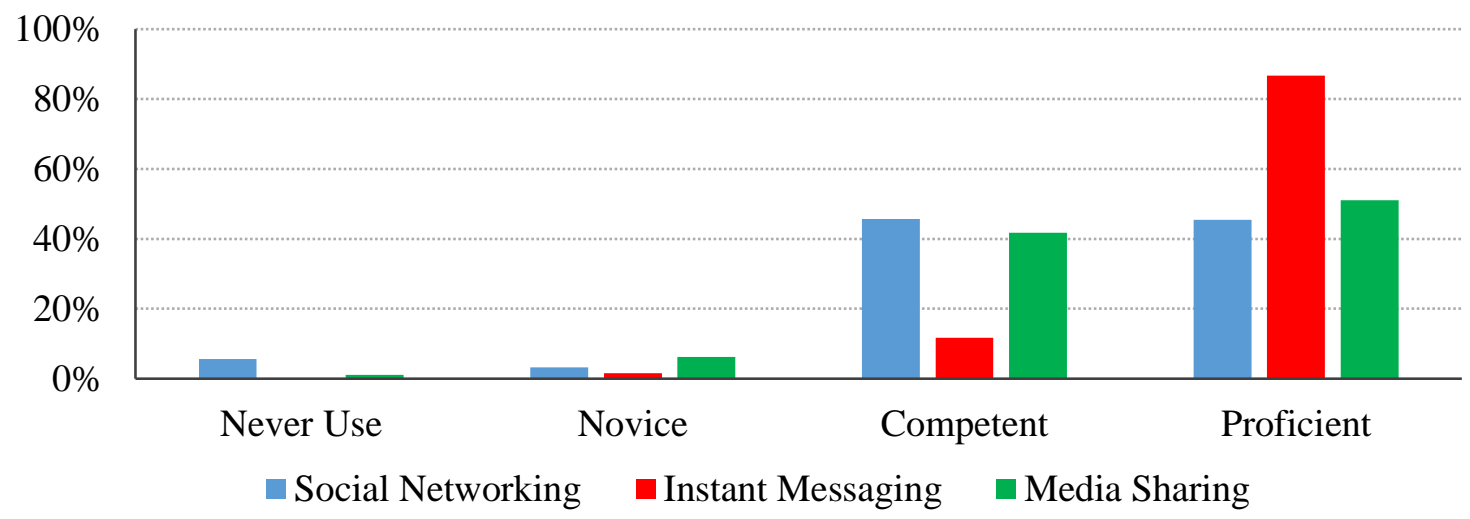

Figure 1: Faculty's comfort level with Web 2.0 Tools

\section{Conclusion and Recommendations}

The aim of this study was to determine the challenges to the faculties and changes in the Saudi universities required when implementing Web 2.0. The results, in general, demonstrated that the faculties are ready to implement this technology because they believe that this approach would not only improve student learning but also have other educational benefits. Implementing Web 2.0 would provide more learning outcomes

The results of this study showed that faculty members are willing to integrate these Web 2.0 into their courses not only because they believed that would improve student's learning but also for other benefits such as interaction among students, interaction between student and faculty and student engagement and grades. Moreover, the results showed that the participants' level of expertise with the Web 2.0 tools included in the study is relatively high, however, they may find it somehow challenging to integrate these tools in their courses. This might be a result of lack of knowledge or training on how to use Web 2.0 effectively. Institutions could encourage more integration by designing faculty development programs or training that build on the experience that these faculty members have instead of introducing a new tool. In addition, colleges and departments may want to facilitate a dialog between their faculty members and encourage them to share their experience with integrating Web 2.0 tools in the classroom. This would motivate faculty who still have doubts about the educational benefits of using Web 2.0 tools in teaching and learning. 
Future research could focus on further investigating other possible factors that would influence faculty use of Web 2.0 tools. Also, since most of the universities in Saudi Arabia have separated campuses for male and female, it would be beneficial to examine the differences if any regarding actual use and intention to use Web 2.0 tools in teaching between male and female faculty. 


\section{References}

Aifan, H. (2015). Saudi students' attitudes toward using social media to support learning (Doctoral dissertation, University of Kansas). Retrieved from https://kuscholarworks.ku.edu/bitstream/handle/1808/19498/Aifan_ku_0099D_13943_DATA_1.pdf;s equence $=1$

Alkhalaf, S., Nguyen, J., Nguyen, A., \& Drew, S. (2013). Online learner satisfaction and collaborative learning: Evidence from Saudi Arabia. International Journal of Information and Communication Technology Education, (2), 66-78.

Alturki, U. (2014). The development of online distance education in Saudi Arabia. eLearn Magazine. Retrieved from http://elearnmag.acm.org/archive.cfm?aid=2673861

Al-Asmari, A. M., \& Khan, M. S. R. (2014). E-learning in Saudi Arabia: Past, present and future. Near \& Middle Eastern Journal of Research in Education, 2014(1), 1-11.

Al-Hojailan, M. I. A. (2013). The effectiveness of the social network in higher education in Saudi Arabia: Action research to develop an e-learning conceptual model based on blog tools (Doctoral thesis, De Montfort University, Leicester, England). Retrieved from http://hdl.handle.net/2086/9505

Al-Khalifa, H. (2010). Elearning in Saudi Arabia. In U. Demiray (Ed.), Cases on challenges facing elearning and national development: Institutional studies and practices. E-Learning practices (pp. 745-772). Eskisehir-Turkey: Anadolu University.

Barnett, M., Keating, T., Harwook, W., \& Saam, J. (2004). Using emerging technologies to help bridge the gap between university theory and classroom practice: Challenges and successes. School Sciences \& Mathematics, 102(6), 299-314.

Collins, A., \& Halverson, R. (2010). The second educational revolution: Rethinking education in the age of technology. Journal of Computer Assisted Learning, 26(1), 18-27.

Harpe, S. E. (2015). How to analyze Likert and other rating scale data. Currents in Pharmacy Teaching and Learning, 7(6), 836-850.

Higher Education Statistics. (2017). The Saudi Ministry of Education. Retrieved from https://departments.moe.gov.sa/PLANNINGINFORMATION/RELATEDDEPARTMENTS/EDUCATIO NSTATISTICSCENTER/EDUCATIONDETAILEDREPORTS/Pages/default.aspx

Kassens-Noor, E. (2012). Twitter as a teaching practice to enhance active and informal learning in higher education: The case of sustainable tweets. Active Learning in Higher Education, 13(1), 9-21.

Khawaji, T. M. N. (2016). Web 2.0 technology: Social learning tools in higher education in Saudi Arabia (Doctoral thesis, Queensland University of Technology, Brisbane, Queensland, Australia). Retrieved from http://eprints.qut.edu.au/93426/

Konstantinidis, A., Theodostadou, D., \& Pappos, C. (2013). Web 2.0 tools for supporting teaching. Turkish Online Journal of Distance Education, 14(4), 287-295.

Mason, L. L. (2016). Are we ready to Web 2.0? Web 2.0 in higher education classrooms (Doctoral dissertation, Wilmington University). Retrieved from: https://search.proquest.com/docview/1782296776

Seo, K. K. J. (Ed.). (2013). Using social media effectively in the classroom : Blogs, wikis, twitter, and more. New York: Routledge. 